\title{
THE IDENTIFICATION OF LOGICAL THINKING ABILITY BASED ON GENDER IN PHYSICS TEACHERS PROSPECTIVE STUDENTS
}

\author{
Sondang R Manurung ${ }^{1 *}$, Deo Demonta Panggabean ${ }^{1}$ \\ ${ }^{1}$ Faculty of Mathematics and Science, State University of Medan, Medan, Indonesia \\ *Corresponding Author: sondangrina@gmail.com
}

\begin{abstract}
The purpose of this study is to examine the ability to think logically in physics teachers candidates based on gender. The study was carried out in Medan State University that is acknowledged as one of leading Teaching-based Institution (locally known as Lembaga Pendidikan Tenaga Kependidikan, henceforth abbreviated as LPTK) in Medan. This research used an instrument that further examining the Test of Logical Thinking (TOLT). The total research sample is 70 people, consisting of 27 male and 43 female students. The results showed that male students have a higher logical thinking ability than female students. The implication of the result is discussed.
\end{abstract}

Keywords: Logical Thinking, Gender, Physics Teachers Prospective Student, Medan State University

\section{INTRODUCTION}

The theory of intellectual development (cognitive) Piaget has influenced various fields of science, such as psychology, philosophy, and education. The theory widely studied today that affect the ability of science education. Piaget (1964) introduced the concept of intellectual development as the ability to think logically that a person's mental capacity to reason. Reasoning is the ability to inference the conclusion of one or more premises. This capability requires testing the relations between the statements and data logically. In the process of reasoning ability of logical reasoning is necessary, because reasoning is ability to identify or add an argument of logic that is required to solve the problem. According to Piaget (1964) there are five reasoning operations, namely (1) the proportional reasoning, (2) controlling variables, (3) probabilistic reasoning, (4) correlational reasoning, and (5) combinatorial reasoning.

At the stage of formal operations children are also able to think combinatorial. When a child is faced with a problem, he can isolate the factors to arrive at a solution of such problems (Inherder \& Piaget, 1958). Thus, students who belong to the formal operation when is faced on a problem it will be able to lay out all the possibilities that may be of all the variables are provided. Cognitive development follows the order as follows: (a) The level of enactive (activities), individuals have the object or experience events in the surrounding world; (b) Level Ikonic (pictures, images), Individual change, mark and store the events or objects in the form of mental images. In other words, people may think back (in his mind) events (objects) that have been experienced (known) even if that event is no longer in front of him; and (c) Level of symbolic, Individuals can then be expressed in the form of mental images and language symbols. When encountering these symbols, image of mental marked by a symbol that can be recognized back in. At the symbolic level, the individual is able to think of abstract something. With the ability to abstract the individual can develop hypotheses and can foresee the possibilities that will happen. This capability is because humans are capable of reasoning, people understand the symbols of physics (physics objects), such as symbol of the atomic is spherical, electric lines symbol style stripe-shaped, electrical charge positive symbolized by "+" and the negative charge symbolized " - "and so abstract can be received in thinking, because compatibility between the maturity of the individual to the position of the physical object. By mastering the knowledge of physics objects by the individual, learning outcomes can be achieved with good physics. Having regard to the understanding of formal reasoning, it is clear that a student who wants to succeed in a particular subject or wish to acquire good learning outcomes, of course, must have a certain ability main ability formal reasoning, because physics is part of the natural sciences or science that includes a variety of concepts, ideas, laws and abstract symbols, as well as processes that are not stated clearly even need solving variety are manifold by using formal reasoning abilities.

Formal reasoning ability is a part of the basic capabilities such as talent possessed by each individual that allows them to reach a skill, knowledge and special skills (Lawson, et al., 1978). Reasoning skills greatly affect the outcome of learning physics in general, are not real need formal reasoning to understand it. A student who is able to think logically in learning to understand the concepts of physics, where students are able to study the structure of science itself, then these students will not be behind in learning. Thus, it means that, formal reasoning ability possessed by the students play an important role in mastering the concepts of physics optimally. Formal reasoning 
abilities have also been identified as an important skill for success in the advancement of science and mathematics courses (Bowman, 2010), (Yoon, 2009), (Foster et al., 2010), (Ginsburg, 2007), (Haryanto, 2012), (Koray \& Serdar, 2009).

\section{RESEARCH METHODS}

This research uses descriptive method. Instruments to measure the ability to think logically developed by Tobin, K. G \& .Capie, W (1981). Logical Thinking Test (TOLT) is used to measure the five types of formal reasoning, namely: controlling variables, proportional reasoning, reasoning combinatorial, probabilistic reasoning, and reasoning correlational instrument is shaped multiple-choice test with 10 items and a large selection of justification (excuse). Each respondent choose from 10 items require choosing the correct response and justification (excuse) of a number of alternatives. The trial results showed high reliability (coefficient $\alpha=.85$ ) and confirm that the tests measure the key dimensions are based on the so-called formal thinking. Evidence relating to the validity criteria, shows the correlation coefficients $.80(\mathrm{p}<.0001)$ showed a strong relationship between the two instruments measuring formal reasoning. TOLT contains 5 reasoning, namely: 1. Reasoning associated with a proportional or ratio (items $1 \& 2$ ), 2. reasoning with regard to the control variables (item $3 \& 4$ ), 3.Reasoning associated with the probability (item $5 \& 6$ ); 4. Reasoning relating to correlation (item $7 \& 8$ ); 5. Reasoning related to combinatorial (items 9 and 10). The research location is on one LPTK in Medan. Subjects were students of the third semester physics education. The sample consisted of 70 student teachers, 27 male students and 43 female students. The data obtained in this study were analyzed quantitatively. To determine the difference between the average score of a group of men and women used t-test one direction.

\section{RESULTS AND DISCUSSION}

1. Description of Logical Thinking Data Description

The results of the test's ability to think logically on female students group are shown in Table 1. The ability to think a student at a score of a minimum of 4 and a maximum score of 10, and the median score of 6 is 18 students. Range of scores 0-4 in the category of logical thinking to think the transition, in this study 1 students. Range of scores 5-7 in the category of formal thinking early, in this study a number of 36 students, while the range of scores 8-10 in the category of the end formal thinking of a number of 6 students. Pictures of the bar graph shown in Figure 1.

Table 1. Scores of Logical Thinking Ability on the Female student group

\begin{tabular}{|c|c|c|c|c|c|c|}
\hline No & Proportional & $\begin{array}{c}\text { Variable } \\
\text { Controlling }\end{array}$ & Probability & Corelasional & Combinatorial & Total \\
\hline 1 & 2 & 2 & 2 & 2 & 2 & 10 \\
\hline 2 & 2 & 2 & 2 & 2 & 2 & 10 \\
\hline 3 & 2 & 2 & 2 & 2 & 1 & 9 \\
\hline 4 & 2 & 2 & 2 & 2 & 1 & 9 \\
\hline 5 & 2 & 2 & 2 & 2 & 1 & 9 \\
\hline 6 & 2 & 2 & 2 & 2 & 0 & 8 \\
\hline 7 & 2 & 2 & 2 & 1 & 0 & 7 \\
\hline 8 & 2 & 1 & 2 & 2 & 0 & 7 \\
\hline 9 & 2 & 2 & 0 & 2 & 1 & 7 \\
\hline 10 & 2 & 2 & 0 & 1 & 2 & 7 \\
\hline 11 & 2 & 2 & 0 & 2 & 0 & 6 \\
\hline 12 & 2 & 2 & 0 & 2 & 0 & 6 \\
\hline 13 & 2 & 2 & 2 & 0 & 0 & 6 \\
\hline 14 & 2 & 2 & 2 & 0 & 0 & 6 \\
\hline 15 & 2 & 2 & 0 & 2 & 0 & 6 \\
\hline 16 & 2 & 2 & 0 & 2 & 0 & 6 \\
\hline 17 & 1 & 2 & 0 & 1 & 2 & 6 \\
\hline 18 & 2 & 1 & 2 & 1 & 0 & 6 \\
\hline 19 & 2 & 0 & 2 & 2 & 0 & 6 \\
\hline 20 & 2 & 1 & 1 & 1 & 0 & 5 \\
\hline 21 & 2 & 2 & 1 & & & 5 \\
\hline 22 & 1 & 2 & 0 & 0 & 2 & 5 \\
\hline 23 & 1 & 0 & 2 & 2 & 0 & 5 \\
\hline 24 & 2 & 2 & 1 & 0 & 0 & 5 \\
\hline 25 & 2 & 2 & 0 & 0 & 1 & 5 \\
\hline 26 & 2 & 2 & 0 & 0 & 0 & 4 \\
\hline
\end{tabular}




\begin{tabular}{|l|l|l|l|l|l|l|}
\hline 27 & 2 & 2 & 2 & 0 & 0 & 6 \\
\hline 28 & 1 & 2 & 2 & 1 & 0 & 6 \\
\hline 29 & 2 & 2 & 0 & 2 & 0 & 6 \\
\hline 30 & 1 & 2 & 1 & 0 & 2 & 6 \\
\hline 31 & 1 & 2 & 0 & 1 & 2 & 6 \\
\hline 32 & 2 & 2 & 0 & 1 & 1 & 6 \\
\hline 33 & 2 & 1 & 2 & 1 & 0 & 6 \\
\hline 34 & 2 & 0 & 2 & 2 & 0 & 6 \\
\hline 35 & 2 & 1 & 1 & 1 & 0 & 5 \\
\hline 36 & 2 & 2 & 0 & 0 & 1 & 5 \\
\hline 37 & 2 & 2 & 1 & 0 & 0 & 5 \\
\hline 38 & 2 & 2 & 0 & 0 & 1 & 5 \\
\hline 39 & 1 & 2 & 0 & 0 & 2 & 5 \\
\hline 40 & 1 & 0 & 2 & 1 & 0 & 5 \\
\hline 41 & 2 & 2 & 1 & 0 & 0 & 5 \\
\hline 42 & 1 & 2 & 2 & 0 & 0 & 5 \\
\hline 43 & 1 & 2 & 2 & 1 & 0 & 6 \\
\hline
\end{tabular}

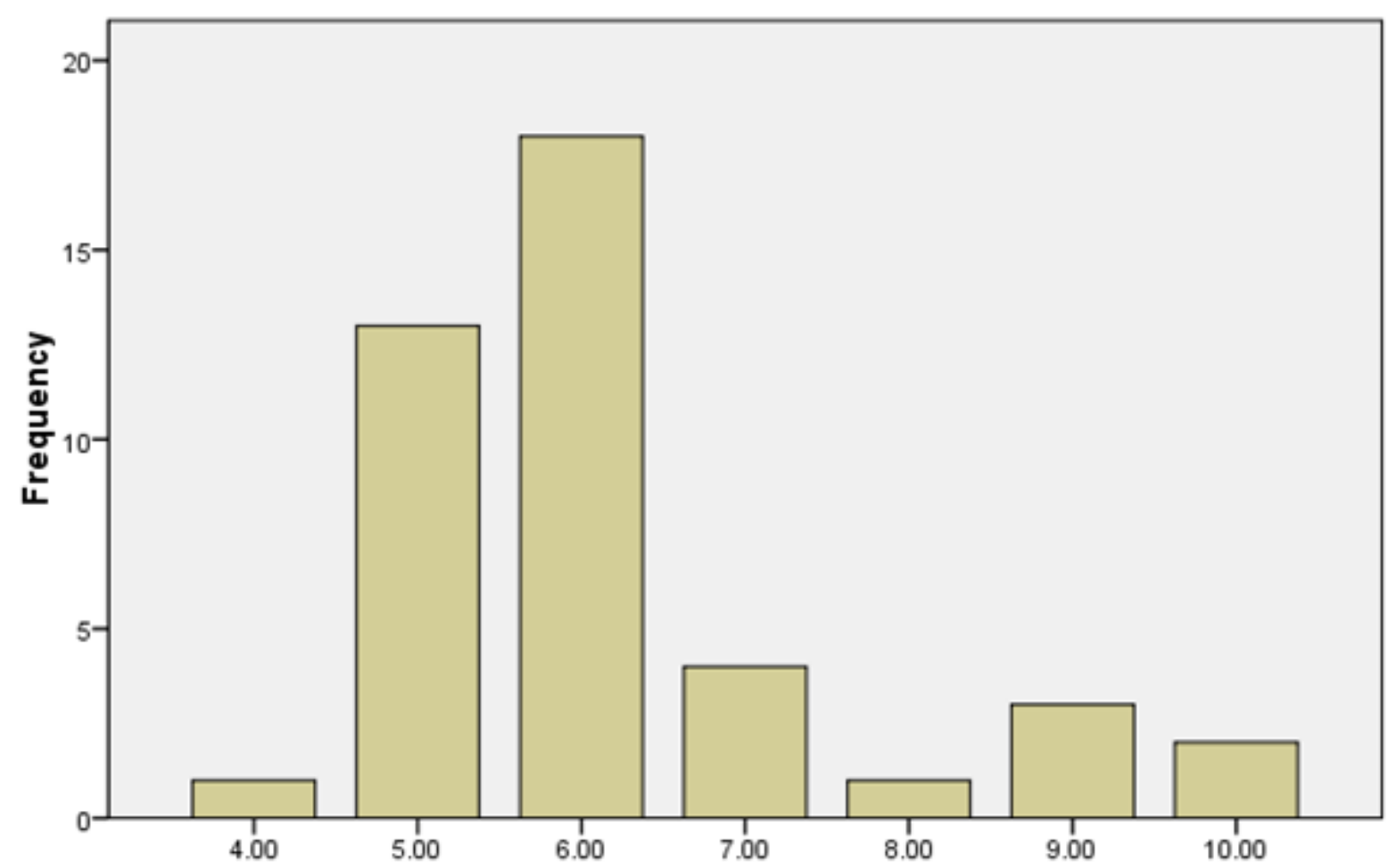

Female Group

Figure 1. Histograf Graph of Scores logic thinking ability female students group

The test results in the ability to think logically groups of male are shown in Table 2 . The ability to think student scores a minimum of 5 and a maximum score of 10, and the median skor 7 ie number 6 students. Range of scores 57 in the category of formal thinking early, in this study a number of 15 students, while the range of scores 8-10 in the category of the end formal thinking of a number of 12 students. Histogram graphs picture of thinking ability scores male student group is shown in Figure 2.

Table 2. Calculation of Logical Thinking Ability Scores on MaIe Student Group

\begin{tabular}{|c|c|c|c|c|c|c|}
\hline No & Proportional & $\begin{array}{c}\text { Variabel } \\
\text { Controlling }\end{array}$ & Probability & Corelational & Combinatorial & Total \\
\hline 1 & 2 & 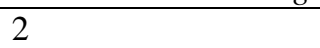 & 2 & 2 & 2 & 10 \\
\hline 2 & 2 & 1 & 2 & 2 & 2 & 9 \\
\hline 3 & 2 & 2 & 2 & 2 & 0 & 8 \\
\hline
\end{tabular}




\begin{tabular}{|l|l|l|l|l|l|l|}
\hline 4 & 2 & 2 & 2 & 2 & 0 & 7 \\
\hline 5 & 1 & 2 & 1 & 0 & 2 & 6 \\
\hline 6 & 2 & 2 & 0 & 1 & 1 & 6 \\
\hline 7 & 2 & 2 & 0 & 0 & 1 & 5 \\
\hline 8 & 2 & 2 & 1 & 0 & 0 & 5 \\
\hline 9 & 1 & 2 & 2 & 0 & 0 & 5 \\
\hline 10 & 1 & 2 & 1 & 1 & 0 & 5 \\
\hline 11 & 2 & 2 & 2 & 2 & 2 & 10 \\
\hline 12 & 2 & 2 & 2 & 2 & 2 & 10 \\
\hline 13 & 2 & 2 & 2 & 2 & 2 & 10 \\
\hline 14 & 2 & 2 & 2 & 2 & 1 & 9 \\
\hline 15 & 2 & 2 & 2 & 2 & 1 & 9 \\
\hline 16 & 2 & 2 & 2 & 2 & 1 & 9 \\
\hline 17 & 2 & 1 & 2 & 2 & 2 & 9 \\
\hline 18 & 2 & 2 & 2 & 2 & 0 & 8 \\
\hline 19 & 2 & 2 & 2 & 2 & 0 & 8 \\
\hline 20 & 2 & 2 & 2 & 0 & 1 & 7 \\
\hline 21 & 2 & 2 & 1 & 2 & 0 & 7 \\
\hline 22 & 2 & 1 & 2 & 2 & 0 & 7 \\
\hline 23 & 2 & 2 & 0 & 2 & 1 & 7 \\
\hline 24 & 2 & 2 & 0 & 1 & 2 & 7 \\
\hline 25 & 2 & 2 & 0 & 2 & 0 & 6 \\
\hline 26 & 2 & 2 & 0 & 2 & 0 & 6 \\
\hline 27 & 2 & 2 & 2 & 0 & 0 & 6 \\
\hline
\end{tabular}

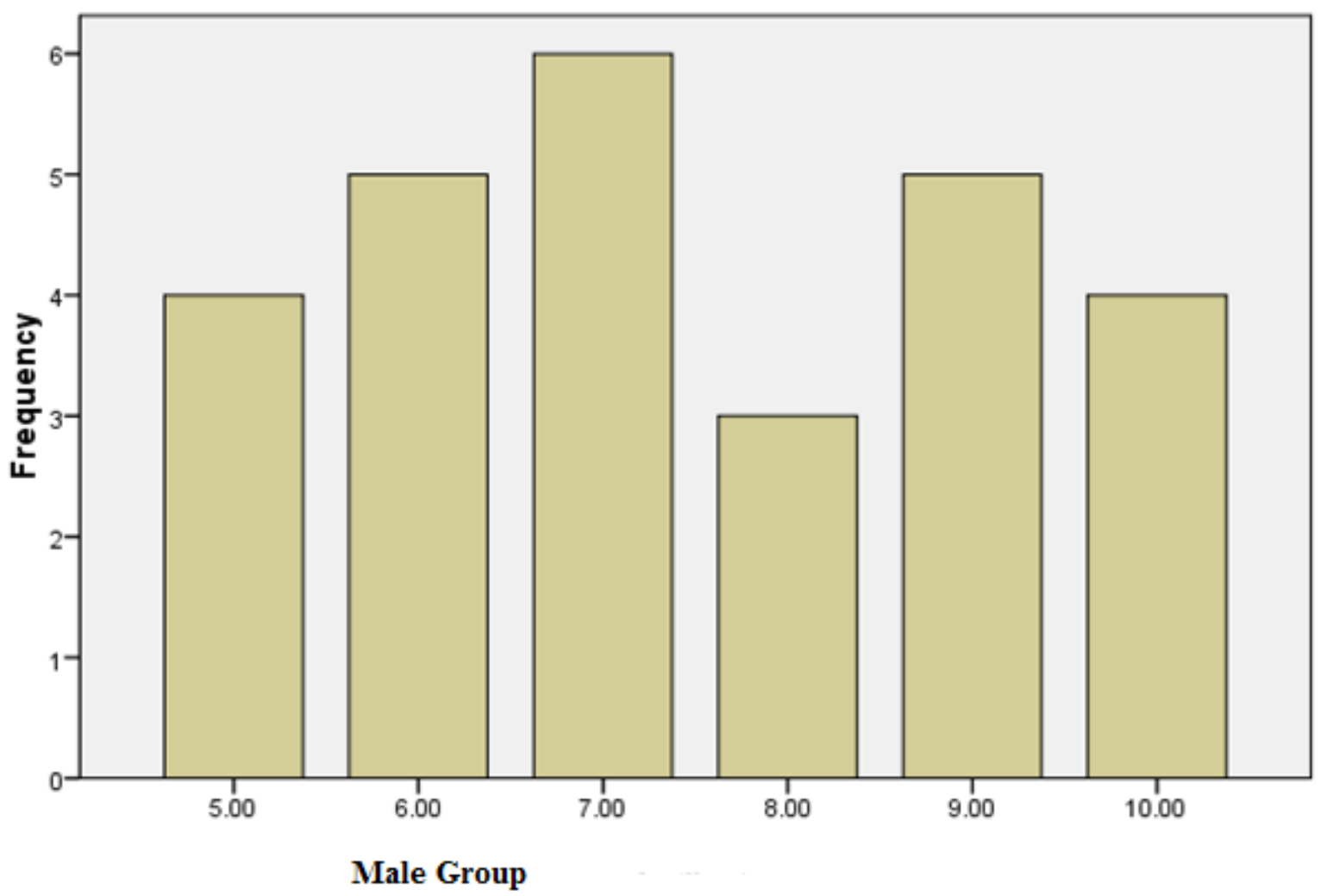

Figure 2. Bar graph of of Logical Thinking Ability Scores on MaIe Student Group

See average scores between male and female students shown in Table 3, the average score of 7.48 males other than their larger average score of the female's group by 6.18. In each of the five aspects of logical thinking ability, a group of male was higher than female. Reasoning of proportional is higher than four other reasoning in groups of 
male and groups of women, followed by the second control variable reasoning. Furthermore is followed in third place in the group of male is correlational reasoning and probability reasoning in female group. Fourth Ranked is probalistic reasoning in male group and correlational reasoning in female group. While ranked last is followed combinatorial reasoning in the male group and female group.

Tabel.3. Display of the average score of male students group $(n=27)$ and female student group $(n=43)$ in 5 reasoning tests TOLT

\begin{tabular}{|l|l|l|l|l|l|l|}
\hline & \multicolumn{2}{|l|}{ Male } & Female & \multicolumn{2}{l|}{ Total } \\
\hline Aspect of Reasoning & $\begin{array}{l}\text { Score of } \\
\text { Average }\end{array}$ & $\begin{array}{l}\text { Std } \\
\text { Deviation }\end{array}$ & $\begin{array}{l}\text { Score of } \\
\text { Average }\end{array}$ & $\begin{array}{l}\text { Std } \\
\text { Deviation }\end{array}$ & $\begin{array}{l}\text { Score } \\
\text { Average }\end{array}$ & $\begin{array}{l}\text { Std. } \\
\text { Deviation }\end{array}$ \\
\hline Proportional & 1.89 & .32 & 1.77 & .43 & 1.81 & .39 \\
\hline Variable Controlling & 1.89 & .32 & 1.69 & .64 & 1.77 & .54 \\
\hline Probability & 1.41 & .84 & 1.09 & .92 & 1.21 & .89 \\
\hline Corelational & 1.44 & .85 & 1.05 & .85 & 1.20 & .87 \\
\hline Combinatorial & .85 & .86 & .57 & .80 & .68 & .83 \\
\hline Total & 7.48 & 3,19 & 6,18 & 3,64 & 6,68 & 3,53 \\
\hline
\end{tabular}

Table One-Sample Statistics describing the value pretest value variable statistics as follows: overall sampling number 70 where the number of men as much as men 27 and the number of women as many as 43 people. The average value of the ability to think of men amounted to 7, 48 and a standard deviation of 3.19. For women, the average value of the ability to think at 6.81, the standard deviation of 3.64, as shown in Table 4 .

Table 4. Display of party $t$ test between groups of men and women

\begin{tabular}{|l|l|l|l|l|l|}
\hline No & $\begin{array}{l}\text { Data } \\
\text { Postest }\end{array}$ & $\begin{array}{l}\text { Value of } \\
\text { Average } \\
\text { and } \\
\text { standard } \\
\text { deviation }\end{array}$ & thitung & $t_{\text {tabel }}$ & Conclution \\
\hline 1 & Male Group & $\begin{array}{l}\mathbf{7 . 4 8} \\
\mathbf{3 , 1 9}\end{array}$ & $\mathbf{2 , 0 6}$ & $\mathbf{1 , 6 7}$ & $\begin{array}{l}\text { Intellectual development of male } \\
\text { group is higher than intellectual } \\
\text { development of female group }\end{array}$ \\
\hline 2 & Female Group & $\begin{array}{l}\mathbf{6 , 1 8} \\
\mathbf{3 , 6 4}\end{array}$ & & \\
\hline
\end{tabular}

Based on Table 4, the student group of men had a score of 7.48 with a standard deviation of 3, 195 and a group of female students had an average score of 6.18 with a standard deviation of 3.64. The above data shows that thitung > table (2.06> 1.667), so it can be concluded that the student group men have a higher intellectual development than the group of women students.

Translated from TOLT reliability, demonstrated research results good enough. It turned out that almost $100 \%$ of students already at the level of formal development. Classification of subjects in the stage of cognitive development is derived directly from Piaget's theory. On the other hand, the need to classify the subjects in a stage of intellectual development is not fully justified from the results of this study because the basic premise of the theory of Piaget said that the formal reasoning is an integrated mode and general intellectual functioning is not confirmed. In connection with student achievement, the results of research carried out showed that girls had significantly higher achievement than boys. In this study shows boys, have superior performance significantly than girls on the item reasoning probabilistic (Koray \& Serdar, 2009). (Lewis \& Lewis, 2007), (McCormack, 2009), (NSSL, 2011). Besides, Zurida and Ismail (2008) stated there is a relationship between science process skills with the ability to think logic of $\mathrm{r}=$ 0.5994. Furthermore .Sadia (2007) shows the results of his research, which in general irrespective of treatment (treatment) and school level, it turns out the vast majority (83.82\%) high school students of class I in Buleleng thinking skills that are in the formal qualification of being, and only $13.44 \%$ are highly qualified and even there are $2.74 \%$ of students who qualified low formal thinking ability. Furthermore, he stated that the Model PBL / LCM was effective in developing formal thinking skills of students. 


\section{CONCLUSION}

On the basis of the results of research and discussion are the results of the test's ability to think logically in groups of women showed a score of a minimum of 4 and a maximum score of 10, and the median score of 6 is 18 men. Range of scores 0-4 in the category of logical thinking to think the transition, in this study 1 students. Range of scores 5-7 in the category of formal thinking early, in this study a number of 36 students, while the range of scores 8-10 in the category of formal thinking the end of a number of 6 students. The test results in the ability to think logically groups of men showed a score of a minimum of 5 and a maximum score of 10 , and the median skor7 ie number 6 . Range of scores 5-7 in the category of logical thinking formal thinking early, in this study a number of 15 students, while the range of scores 8-10 in the category of formal thinking the end of a number of 12 students. Looks ability to think a group of men is higher. The student group men have a higher intellectual development than the group of women students.

\section{ACKNOWLEDGEMENTS}

The research is funded by the Competitive Grants DP2M Director General of Higher Education Ministry of Education and Culture. Therefore, researchers who receive grants DP2M to thank the Director General of Higher Education which has provided funds, and the opportunity for researchers to conduct research in Physical Education Program, Unimed. On this occasion, the authors would like to thank the Rector and Chairman of the Research Institute of the State University of Medan which has given opportunity to the team of researchers to conduct research. This has helped the research.

\section{REFERENCES}

Fah, Lay Yoon (2009). Logical Thinking Abilities among Form 4 Students in the Interior Division of Sabah, Malaysia. Journal of Science and Mathematics Education in Southeast Asia. 32 (20) pp: 161-187.

Foster D. ; Bookman J. ; and Whittington M. (2010). Do we know our students?: Analyzing Piagetian stages of cognitive development with a paper-pencil instrument. The Ohio State University Department of Human, Community and Resource Development Publications.

Ginsburg D. , Shayer, M. and Coe., R. (2007). Thirty years on- a large anti-Flynn effect? the Piagetian test volume and heaviness norms 1975-2003. British Journal of Educational Psychology, 77:25(41).

Haryanto, Zeni, 2012, Tahap perkembangan intelektual siswa SMP dan SMA dalam kaitannya dengan pembelajaran fisika: kajian berdasarkan teori perkembangan intelektual Jean Piaget, (Disertasi), Bandung: UPI.

Inhelder, B., \& Piaget, J. (1958). The growth of logical thinking: From childhood to adolescence. New York: Basic Books, Inc.

Koray, Ö., \& KÖKSAL Mustafa Serdar. (2009). The effect of creative and critical thinking based laboratory applications on creative and logical thinking abilities of prospective teachers. Asia Pacific Forum on Science Learning and Teaching, 10(1). Article 2. Retrieved from http:// www.ied.edu.hk/apfslt/v10_issue1/koksal/index.htm\#con

Lewis, S.E., \& Lewis. J.E. (2007). Predicting at-risk students in general chemistry: comparing formal thought to a general achievement measure. Chemistry Education Research and Practice, 8(1), 32-51.

McCormack, L.(2009). Cognitive Acceleration across the primary-second level tran- sition. PhD thesis, Dublin City University, August.

NSSL (2011). Cognitive Development of Greek Students. the National Study of Student Learning (NSSL) at:

http://www.examiner.com/article/cognitive-development-of-greek-students (on 10th June 2013.

Piaget, J. (1964). "Development and Learning. In Ripple, R. and Rockcastle, V. (Eds.). Piaget Rediscovered . Ithaca: Cornel University.

Sadia, I Wayan. (2007).Kemampuan Berpikir Formal Siswa 'Sma Melalui Penerapan Model Pembelajaran "Problem Based Learning" Dan "Cycle Learning" Dalam Pembelajaran Fisika. Jurnal Pendidikan dan Pengajaran UNDIKSHA, No. 1 TH. XXXX Januari 2007.

Tobin, K., \& Capie, W. (1981). The Development And Validation Of A Group Test Of Logical Thinking. Educational And Psychologikal Measurement, 41, 413-423.

Zurida, Haji Ismail And Ismail, Jusoh I(2008). Relationship Between Science Process Skills And Logical Thinking Abilities Of Malaysian Students. Journal Of Science And Mathematics Education In S.E. Asia Vol. Xxiv, No. 2 